\title{
Perbaikan Citra Menggunakan Metode Contrast Stretching
}

\author{
Supiyanto $^{1^{*}}$, Titik Suparwati \\ ${ }^{1}$ Jurusan Matematika, Fakultas MIPA, Universitas Cenderawasih \\ Jl. Kamp Walker Kampus Baru Waena Jayapura \\ *Email korespondensi: supi6976@gmail.com
}

\begin{abstract}
Abstrak
Kontras citra yang tidak baik karena terlalu terang atau terlalu gelap tidak dapat memberikan informasi yang baik. Oleh karena itu, diperlukan metode untuk meningkatkan kualitas citra, sehingga informasi yang ada di dalam citra dapat disampaikan dengan baik. Contrast stretching adalah salah satu metode untuk perbaikan kualitas citra. Metode ini diharapkan dapat menghasilkan citra yang baru yang lebih baik. Penelitian ini bertujuan menerapkan metode contrast stretching pada sebuah aplikasi atau perangkat lunak yang dapat digunakan untuk memperbaikkan kualitas citra. Data yang digunakan pada penelitian ini berupa data citra grayscale maupun citra RGB (true color), dengan format .BMP atau .JPG, sedangkan pengembangan aplikasinya menggunakan bahasa pemrograman Matlab. Hasil penelitian, metode contrast stretching dapat digunakan untuk perbaikan citra yang mempunytai kualitas citra buruk atau kurang baik misalnya citra terlalu terang/gelap, citra kurang tajam, kabur, dan sebagainya. Metode contrast stretching juga bisa dipakai untuk meningkatkan kualitas citra (image enhancement) dengan cara meratakan histogram yang tadinya mengumpul pada suatu area, sehingga informasi yang terkandung dalam citra terlihat lebih jelas dibandingkan dengan citra asli.
\end{abstract}

Kata kunci: Citra, Contrast Stretching, Histogram, greyscale, RGB (true color) image.

\begin{abstract}
Contrasting images that are not good because they are too bright or too dark cannot provide good information. Therefore, a method is needed to improve the image quality, so that the information in the image can be conveyed properly. Contrast stretching is one of the methods for improving image quality. With this method is expected to produce a new image that is better. The purpose of this research is to apply contrast stretching method to an application or software that can be used to improve image quality. Data used in this study in the form of grayscale image data and RGB imagery (true color), with the format . BMP or . JPG, while the application development uses the Matlab programming language.The results of the study, contrast stretching method can be used to repair image that affects bad or poor image quality such as too bright / dark image, less sharp image, blurry, and so on. Contrast stretching method can also be used to improve image enhancement by leveling the histogram that was collected in an area, so that the information contained in the image is more clearly visible compared to the original image.
\end{abstract}

Keywords: Image, Contrast Stretching, Histogram, greyscale, RGB (true color) image

\section{Pendahuluan}

Citra (image) sebagai salah satu komponen multimedia yang memegang peranan penting sebagai bentuk informasi visual [1]. Suatu citra dapat memberikan informasi lebih banyak daripada yang disajikan dalam bentuk kata-kata (tekstual). Meski kaya informasi, tetapi sering kali citra yang kita miliki terdegrasi karena cacat atau adanya noise, warnanya terlalu kontras, kurang tajam, buram (blur), dan sebagainya [2].

Saat ini sudah banyak digunakan kemera digital sebagai alat untuk mengambil citra, karena kepraktisannya. Permasalahan yang sering terjadi adalah kontras citra yang kurang jelas atau gelap sehingga membuatnya sulit untuk dipahami. Kondisi ini mempengaruhi kualitas pencahayaan citra yang ditangkap. Citra yang terlalu terang atau terlalu gelap tidak dapat memberikan informasi yang terkandung di dalamnya dengan baik. Untuk itu perlu suatu metode untuk perbaikan kualitas citra, agar informasi yang ada di citra dapat tersampaikan dengan baik

Perbaikan kualitas citra (image enhancement) merupakan salah satu proses awal dalam pengolahan citra (image preprocessing). Perbaikan kualitas diperlukan karena seringkali citra yang dijadikan objek pembahasan mempunyai kualitas yang buruk, misalnya citra mengalami derau (noise) pada saat pengiriman melalui saluran 
transmisi, citra terlalu terang/gelap, citra kurang tajam, kabur, dan sebagainya [3]. Melalui operasi pemrosesan awal inilah kualitas citra diperbaiki sehingga selanjutnya citra ini dapat dipergunakan sesuai kebutuhan.

Tujuan perbaikan kualitas citra adalah meningkatkan kualitas citra. Fungsi utama dari pengolahan citra adalah untuk memperbaiki kualitas dari suatu citra sehingga citra dapat dilihat lebih jelas dan informasi yang ada di dalam citra dapat diekstrak dengan tepat. Citra yang terlalu terang atau terlalu gelap dapat menyamarkan informasi yang terkandung dalam citra tersebut. Untuk memperbaiki kualitas citra maka dibutuhkan suatu metode agar citra tersebut dapat disampaikan dengan baik. Metode contrast stretching memiliki kemampuan yang baik dalam perbaikan kualitas citra [4] dan mampu meningkatkan kualitas citra [5].

Metode contrast stretching adalah metode yang dilakukan dengan menambah atau mengurangi contrast (pencahayaan) agar citra tersebut lebih tajam dari citra aslinya [6]. Proses contrast stretching termasuk proses perbaikan citra yang bersifat point processing, yang artinya proses ini hanya tergantung dari nilai intensitas (gray level) satu pixel, tidak tergantung dari pixel lain yang ada di sekitarnya. Contrast stretching merupakan teknik yang digunakan untuk mendapatkan citra baru dengan kontras yang lebih baik daripada kontras dari citra asalnya. Maka dalam penelitian ini akan dikembangkan perbaikan kualitas citra dengan metode contrast stretching dengan citra masukan berupa citra grayscale dan citra RGB (citra berwarna) dengan format .JPG dan .bmp.

Penelitian serupa sebelumnya sudah pernah dilakukan dengan cara operasi titik (point operations), yang akan memproses tiap pixel citra masukan secara individu, yaitu dengan membuat titik yang cenderung gelap menjadi lebih gelap dan yang cenderung terang menjadi lebih terang [7]. Dalam penelitian ini akan dikembangkan perbaikan kualitas citra dengan metode yang sama namun citra masukannya berupa grayscale dan RGB (citra berwarna) yang memiliki format .JPG dan .BMP. Sedangkan untuk pengembangan perangkat lunaknya digunakan program Matlab.

\section{Metode Penelitian}

Secara harafiah, citra (image) adalah gambar pada bidang dua dimensi. Sedangkan ditinjau dari sudut pandang matematis, citra merupakan fungsi continue dari intensitas cahaya pada bidang dua dimensi. Berdasarkan warnanya, citra terbagi atas citra biner yaitu citra yang setiap pixel bernilai 0 atau 1 ; citra skala keabuan (citra gray scale) yaitu citra yang nilai pixel-nya bernilai 0 sampai 255 dan citra warna (citra true color) yaitu citra yang warnya dibentuk dari kombinasi tiga warna dasar yaitu merah hijau biru atau dikenal dengan citra RGB (Red Green Blue) dengan nilai pixel-nya masing-masing bernilai 0 sampai 255 . Kontras suatu citra menyatakan sebaran terang (lightness) dan gelap (darkness) di dalam sebuah citra. Citra dengan kontras yang baik, komposisi gelap dan terang tersebar secara merata sedangkan citra dengan kontras rendah dicirikan oleh sebagian besar komposisi citranya tidak merata, pixel akan terkonsentrasi pada sisi kiri, sisi kanan, atau tengah.

Berdasarkan grafik penyebaran nilai-nilai intensitas pixel dari suatu citra (histogram), histogram citra dengan kontras rendah, semua pixel akan terkonsentrasi pada sisi kiri (citra gelap), sisi kanan (citra terang), atau tengah. Semua pixel akan terkelompok secara rapat pada suatu sisi tertentu. Citra dengan kontras tinggi memiliki daerah gelap dan terang yang luas. Histogram citra dengan kontras tinggi memiliki dua puncak besar, satu puncak terkonsentrasi pada sisi kanan histogram. Sedangkan untuk citra dengan kontras yang bagus menampilkan rentangan nilai pixel yang lebar. Histogramnya relatif menunjukkan distibusi nilai pixel yang seragam, tidak memiliki puncak utama, atau tidak memiliki lembah.

Perenggangan kontras adalah teknik yang sangat berguna untuk memperbaiki kontras citra terutama citra yang memiliki kontras rendah. Teknik ini bekerja dengan baik pada citra yang memiliki distribusi Gaussian atau mendekati distribusi Gaussian [7]. Pada peregangan kontras, setiap pixel pada citra A ditransformasikan dengan menggunakan fungsi sebagai berikut:

$$
b(i, j)=\frac{a(i, j)}{d-c}(L-1)
$$

dengan $b(i, j)$ dan $a(i, j)$ berturut-turut pixel sesudah dan sebelum ditransformasi pada koordinat $(i, j), c$ dan $d$ berturut-turut menyatakan nilai maksimum dan minimum dari pixel citra input, dan $L$ menyatakan nilai grayscale maksimum yaitu $255^{\circ}$. Bila nilai pixel lebih lebih kecil dari 0 maka akan dijadikan 0 dan bila lebih lebar dari $(L-1)$ maka akan dijadikan $(L-1)$.

Contrast stretching merupakan teknik yang digunakan untuk mendapatkan citra baru dengan kontras yang lebih baik daripada kontras dari citra asalnya. Metode yang dilakukan dengan cara menambah atau mengurangi contrast (pencahayaan) agar citra tersebut lebih tajam dari citra. Proses contrast stretching termasuk proses perbaikan citra yang bersifat point processing, yang artinya proses ini hanya tergantung dari nilai intensitas satu pixel, tidak tergantung dari pixel lain yang ada di sekitarnya.

Pada Gambar 1, $\mathrm{x}$ adalah nilai intensitas atau nilai pixel dari citra sebelum diproses dan y adalah nilai intensitas atau nilai pixel dari citra setelah diproses. Titik $\left(x_{1}, y_{1}\right)$ dan titik $\left(x_{2}, y_{2}\right)$ akan menentukan bentuk dari fungsi transformasi dan penyebaran gray level dari citra yang dihasilkan. Disini diasumsikan bahwa citra memiliki range gray level dari 0 sampai 255 . 


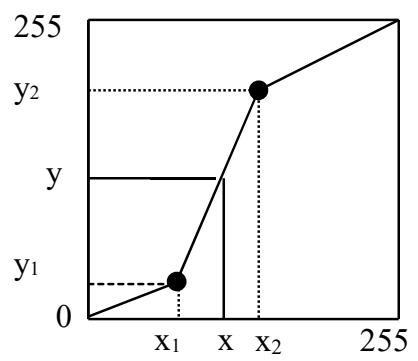

Gambar 1. Transformasi dari kontrol Contrast Stretching

Jika $x_{1}=x_{2}$ dan $y_{2}=x_{2}$ maka transformasi akan berbentuk garis lurus yang berarti tidak ada perubahan gray level pada citra yang dihasilkan. Untuk menghitung nilai hasil transformasi $(y)$ tersebut, kita dapat menentukan dengan cara mencari nilai $y$ untuk nilai $x$ yang diketahui.

Untuk :

$$
\begin{aligned}
& >\quad 0 \leq x<x_{1} \text {, maka } y=y_{1} *\left(x / x_{1}\right) \\
& >\quad x_{1} \leq x<x_{2} \text {, maka } y=y_{1}+\frac{\left(y_{2}-y_{1}\right) *\left(x-x_{1}\right)}{\left(x_{2}-x_{1}\right)} \\
& >\quad x_{2} \leq x \leq 255 \text {, maka } y=y_{2}+\frac{\left(255-y_{2}\right) *\left(x-x_{2}\right)}{\left(255-x_{2}\right)}
\end{aligned}
$$

dengan : $x_{1}, x_{2}, y_{1}, y_{2}=$ sembarang nilai, besarannya dari 0 sampai 255 .

Sebaiknya nilai $x_{1} \leq x_{2}$ dan nilai $y_{1} \leq y_{2}$, hal ini digunakan untuk menghindari hasil negatif dari proses operasi $\left(x_{2}-x_{1}\right)$ atau $\left(y_{2}-y_{1}\right)$, sehingga diperoleh nilai intensitas atau nilai pixel yang baru diantara 0 sampai 255.

\section{Hasil dan Pembahasan}

Proses pengembangan aplikasi dengan metode contrast stretching dilakukan dengan menggunakan bahasa pemrograman Matlab R2012b. Program selanjutnya diuji dengan menggunakan beberapa citra uji yang memiliki kontras rendah atau citra gelap, dengan berbagai kecenderungan kecerahan, yaitu citra berwarna gelap, citra berwarna, serta gambar grayscale. Hasil pengembangan dan pengujian aplikasi sebagai berikut :

\subsection{Halaman Beranda}

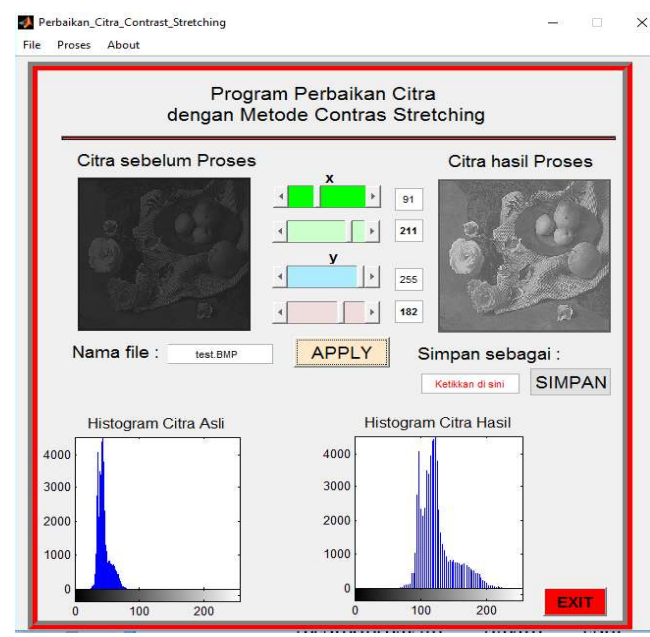

Gambar 2. Halaman antar muka

Halaman beranda merupakan halaman pertama yang tampil saat aplikasi dijalankan. Bentuk halaman beranda dapat dilihat pada Gambar 2. 


\subsection{Pengujian}

Untuk pengujian ini ada dua citra yang akan ditinjau yaitu citra grayscale dan citra warna. Pada pengujian citra grayscale, citra uji yang digunakan berupa citra yang memiliki kontras rendah. Gambar 3.a contoh citra yang memiliki kontras rendah, citra tampak gelap. Histogram untuk setiap elemen dari citra ini sempit dan terletak di bagian kiri (Gambar 3.b).

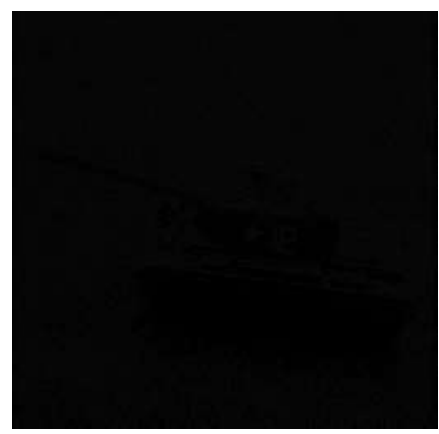

(a)

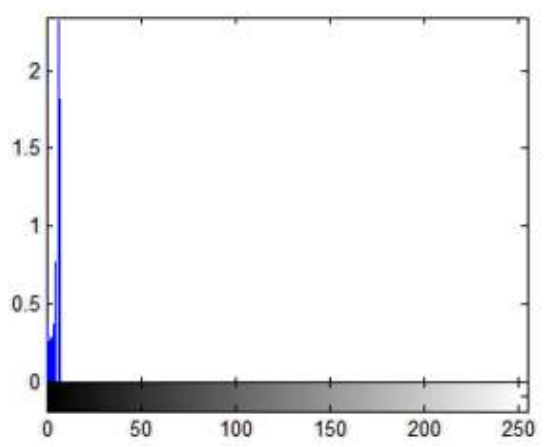

(b)

Gambar 3. Citra (a) tank.bmp dan histogramnya (b) yang memiliki kontras rendah

Sedangkan hasil peningkatan kontras menggunakan metode contrast stretching dengan nilai $x_{1}=10, x_{2}=$ $5, y_{1}=255$ dan $y_{2}=10$ dapat dilihat pada Gambar 4.a. Hasilnya gambar tampak lebih tajam bandingkan dengan gambar aslinya. Histogram dari semua elemen warna diperlebar dan mencakup semua rentang skala abu-abu, yaitu 0-255 (Gambar 4.b).

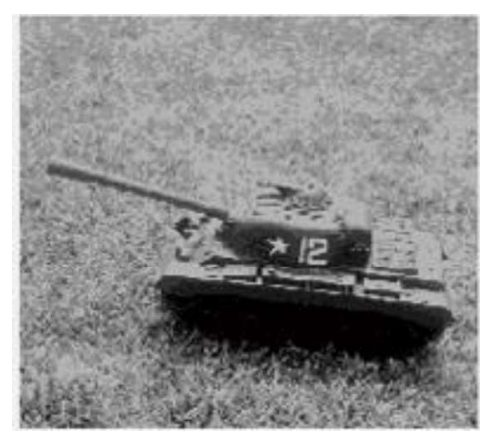

(a)

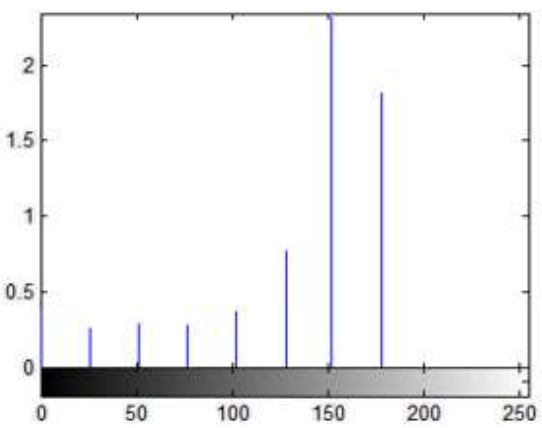

(b)

Gambar 4. Hasil program peningkatan kontras menggunakan metode contrast stretching dengan nilai $x_{1}=10, x_{2}=5, y_{1}=255$ dan $y_{2}=10$, (a) tank.bmp, (b) histogram dari tank.bmp

Berikut ini tampilan program aplikasi saat proses perbaikan citra grayscale untuk citra tank di atas yang memiliki kontras rendah menggunakan metode contrast stretching.

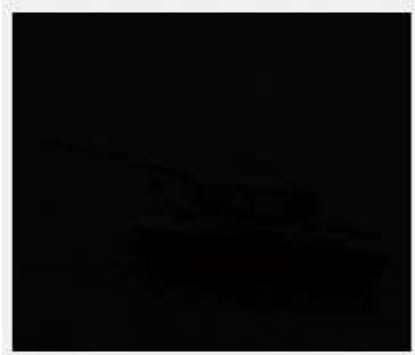

(a)
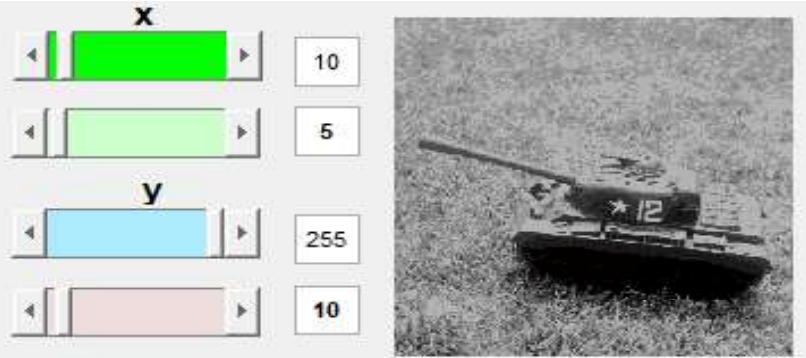

a. Ci(tia) setelah proses

Gambar 5. Tampilan citra sebelum (a) dan setelah (b) proses perbaikan, dengan nilai $x_{1}=10$, $x_{2}=5, y_{1}=255$ dan $y_{2}=10$ 


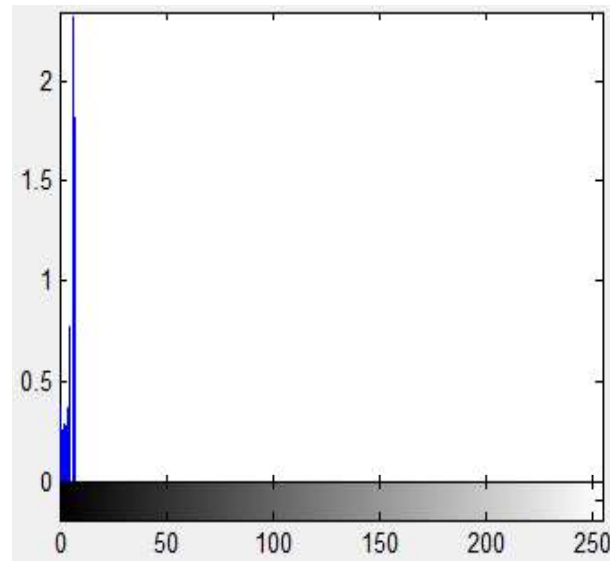

(a)

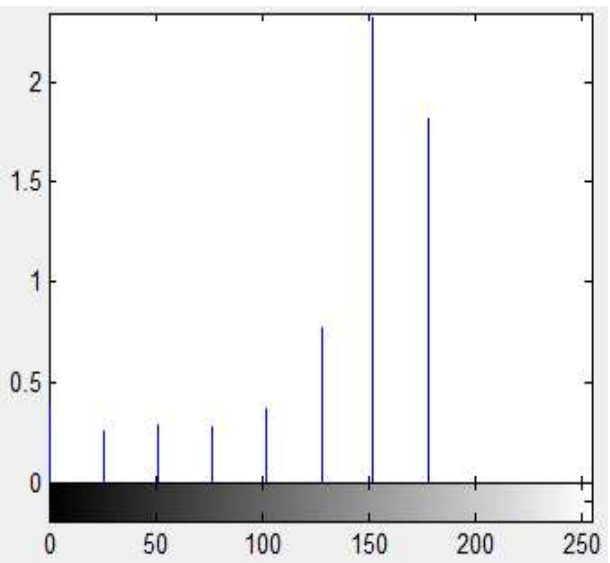

(b)

Gambar 6. Tampilan histogram sebelum (a) dan setelah (b) proses perbaikan, dengan nilai $x_{1}=10, x_{2}=5, y_{1}=255$ dan $y_{2}=10$

Adapun pengujian pada citra warna, Citra warna uji yang digunakan juga berupa citra warna yang memiliki kontras rendah. Citra kucing pada Gambar 7.a contoh citra yang memiliki kontras rendah, citra tampak gelap [8]. Histogram untuk setiap elemen dari citra ini sempit dan terletak di bagian kiri (Gambar 7.b).

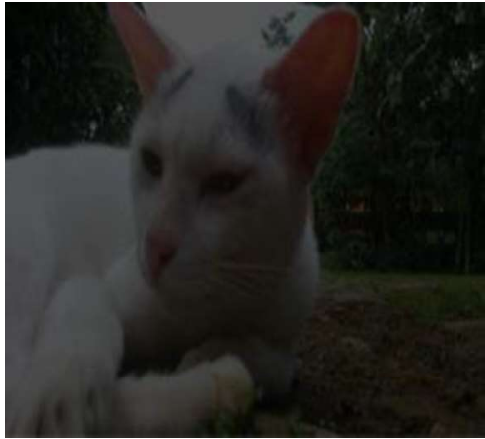

(a)

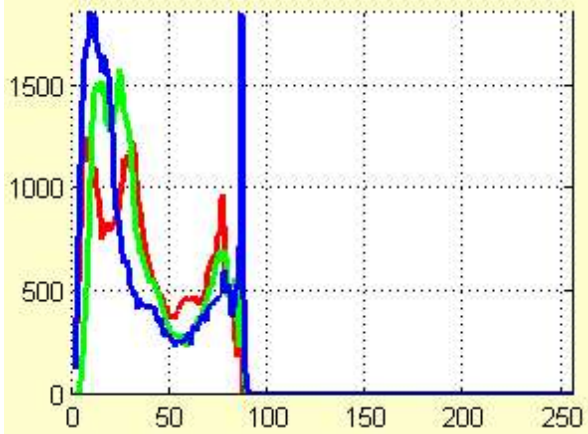

(b)

Gambar 7. Citra dan histogramnya yang memiliki kontras rendah, (a) kucing.bmp, (b) histogram dari kucing.bmp

Untuk hasil peningkatan kontras menggunakan metode contrast stretching dengan nilai $x_{1}=77, x_{2}=182$, $y_{1}=237$ dan $y_{2}=182$ dapat dilihat pada Gambar 8.a. Hasilnya gambar tampak lebih tajam bandingkan dengan gambar aslinya. Histogram dari semua elemen warna diperlebar dan mencakup semua rentang skala abu-abu, yaitu 0-255 (Gambar 8.b).

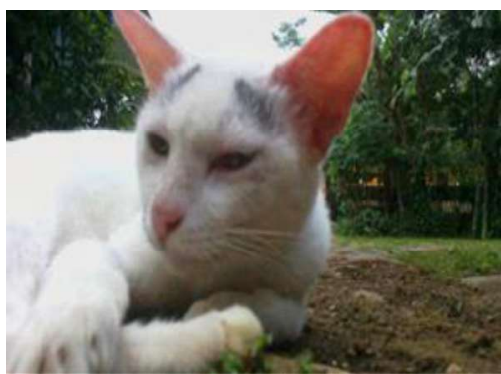

(a)

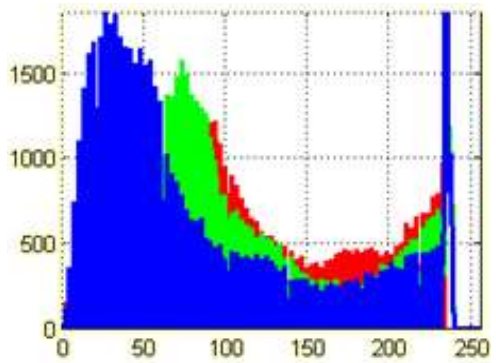

(b)

Gambar 8. Hasil program peningkatan kontras menggunakan metode contrast stretching dengan nilai nilai $x_{1}=77, x_{2}=182, y_{1}=237$ dan $y_{2}=182$, (a) kucing.bmp, (b) histogram dari kucing.bmp 


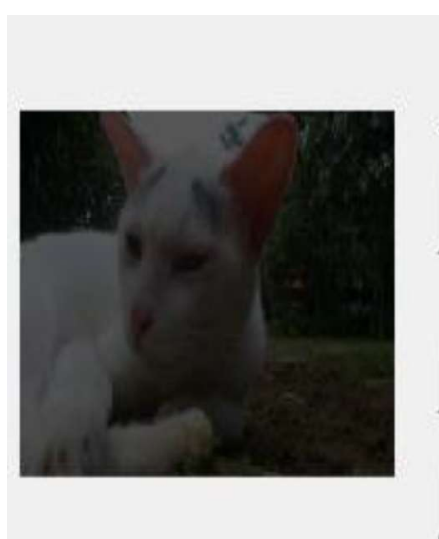

(a)

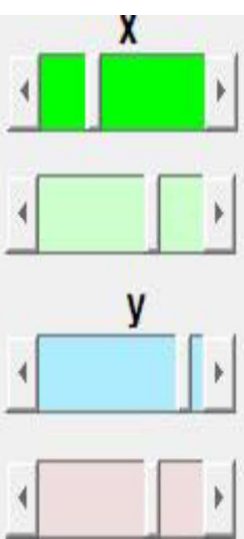

L

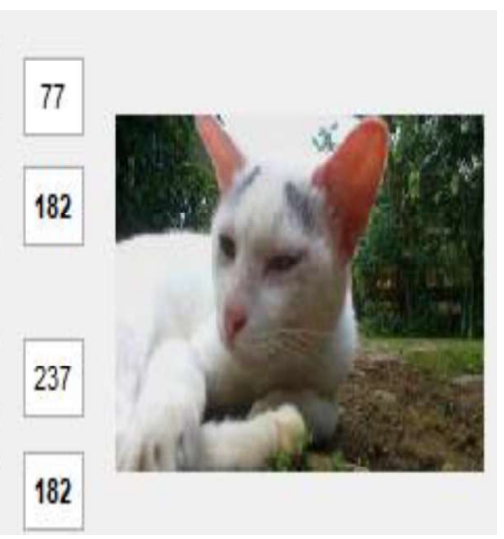

b. Cit(b)setelah proses

Gambar 9. Tampilan citra kucing sebelum (a) dan setelah (b) proses perbaikan, dengan nilai $x_{1}=77, x_{2}=182, y_{1}=237$ dan $y_{2}=182$.

Pada umumnya, penilitian-penelitian sebelumnya selalu mengasumsikan $x_{1} \leq x_{2}$ dan $y_{1} \leq y_{2}$ sedangkan pada penelitian ini tidak hanya dilakukan dengan pengambilan nilai $x_{1} \leq x_{2}$ tetapi juga mengambil nilai $x_{1} \leq x_{2}$, begitu terhadap nilai $y_{1}$ dan $y_{2}$, pada penelitian mengambil juga diambil nilai $y_{1} \geq y_{2}$ dan $y_{1} \leq y_{2}$ untuk menghasilkan hasil citra yang lebih baik

\section{Kesimpulan}

Berdasarkan hasil dan pembahasan dapat disimpulkan bahwa metode contrast stretching dapat diimplementasikan untuk melakukan perbaikan citra terhadap citra greyscale dan citra RGB (true color) yang memiliki kontras rendah atau citra gelap. Hal tersebut menunjukan juga bahwa metode contrast stretching bisa dipakai untuk meningkatkan kualitas citra (image enhancement) dengan cara meratakan histogram yang awalnya mengumpul pada suatu area, sehingga informasi yang terkandung dalam citra akan terlihat lebih jelas dibandingkan dengan citra asli. Metode contrast stretching pada penelitian ini sangat efektif dipakai untuk meningkatkan tingkat kecerahan atau ketajaman citra greyscale dan citra RGB (true color) dengan berformat .BMP atau .JPG. Untuk penelitian lebih lanjut dapat dilakukan melalui peningkatan kualitas citra, tidak hanya menggunakan citra greyscale dan citra RGB (true color) yang memiliki format .JPG dan .bmp tapi dilakukan juga untuk format yang lain dan juga perlu dilakukan membandingkan metode contrast stretching dengan metodemetode lain yang dapat digunakan untuk Perbaikan kualitas citra (image enhancement).

\section{Ucapan Terima Kasih}

Tim peneliti menyampaikan terima kasih kepada Rektor UNCEN untuk dana penelitian dari PNBP UNCEN tahun 2020

\section{Daftar Pustaka:}

[1] Munir, R.. 2004. Pengolahan Citra Digital Dengan pendekatan Algoritmik, Penerbit Andi, Yogyakarta

[2] Novita R. 2011. Analisis Penerapan Metode Median Filter Untuk Mengurangi Noise Pada Citra Digital, Konferensi Nasional Sistem dan Informatika, Bali. Diakses pada tanggal 27/05/2015

[3] Imanuddin, Oktafian R, dan Munawir. 2019. Image Smoothing Menggunakan Metode Mean Filtering, JOINTECS (Journal of Information Technology and Computer Science), Vol 4, No.2.

[4] Mokhtar N R, Harun N H, Mashor M Y, Roseline H, Mustafa N, Adollah R, Adilah H, Nasir N F M. 2009. Image Enhancement Techniques Using Local, Global, Bright, Dark and Partial Contrast Stretching For Acute Leukemia Images, Vol I, London

[5] Jusoh N, Salam R, dan Sayuti M. 2012, Color Image Enhancement using Contrast stretching on a Mobile Device, Faculty of Science and Technology, Universiti Sains Islam Malaysia, Negeri Sembilan, Vol .1, Issue 3, Malaysia

[6] Wakhidah N. 2011. Perbaikan Kualitas Citra Menggunakan Metode Contrast Stretching, Fakultas Teknologi Informasi dan Komunikasi, Universitas Semarang, Semarang

[7] Yudistiawan I. 2018. Implementasi Metode Contrast stretching Untuk Penajaman Citra Digital, Buffer Informatika, Vol. 4.

[8] Galuhsitoresmi. 2017. Operasi Pengolahan Citra Digital Brigthness dan Kontras Pada Citra RGB, at: https://student.blog.dinus.ac.id/galuhsitoresmi/2017/01/17/operasi-pengolahan-citra-digital-brigthnessdan-kontras-pada-citra-rgb. [Accessed 27 September 2020] 